\section{Mangelfull fore- bygging av hjerneslag}

\author{
En studie fra britisk allmennpraksis \\ viser at den primærforebyggende \\ behandling av hjerneslag er for \\ dårlig.
}

Lipidsenkende, antikoagulerende og blodtrykksenkende legemidler kan forebygge hjerneslag hos mange pasienter. I en studie fra britisk allmennpraksis med flere enn 26000 pasienter med hjerneslag i perioden 2009-13 ble forskrivningen av slike legemidler forut for hjerneslaget kartlagt (1). Av dem som fikk sitt første hjerneslag eller transitoriske iskemiske anfall i denne perioden, sto bare omtrent halvparten på slike legemidler. Til tross for at det var klinisk indikasjon for behandling hadde $49 \%$ ikke fått lipidsenkende legemidler, $52 \%$ hadde ikke fått antikoagulerende legemidler og $25 \%$ ikke blodtrykkssenkende legemidler. Forfatterne beregnet at ca. 12000 tilfeller av hjerneslag og transitoriske iskemiske anfall årlig kan forebygges i Storbritannia med bedre primærprofylaktisk behandling.

- Vi må regne med at andelen pasienter som ikke får forskrevet forebyggende behandling, kan ligge på samme nivå i Norge. Men det er mange grunner til at det er slik, og det sier denne studien ingenting om, sier Bjørn Gjelsvik, som er førsteamanuensis ved Avdeling for allmennmedisin ved Universitetet i Oslo. - Det at forholdsvis færre pasienter fikk forskrevet antikoagulantia og statiner, kan tyde på at leger og/eller pasienter er mer bekymret for høyt blodtrykk enn for andre risikofaktorer, eller at de er mer bekymret for bivirkninger ved bruk av slike legemidler, sier han.

- Leger bør drøfte forebyggende behandling med sine pasienter der dette er indisert. Når risikofaktorer er påvist, har legen en etisk forpliktelse til å formidle funnet til pasienten og foreslå tiltak for å redusere sykdomsrisikoen. Når pasienten er godt informert, har vedkommende et grunnlag for å ta en beslutning, sier Gjelsvik.

\section{Petter Morten Pettersen}

Sykehuset Østfold

\section{Litteratur}

1. Turner GM, Calvert M, Feltham MG et al. Underprescribing of Prevention Drugs and Primary Prevention of Stroke and Transient Ischaemic Attack in UK General Practice: A Retrospective Analysis. PLoS Med 2016; 13: e1002169.

\title{
Vaginalring mot hivsmitte
}

\section{Vaginalringer med det antivirale legemidlet dapivirin beskytter til en viss grad mot hivsmitte. Det viser to studier fra det sørøstlige Afrika.}

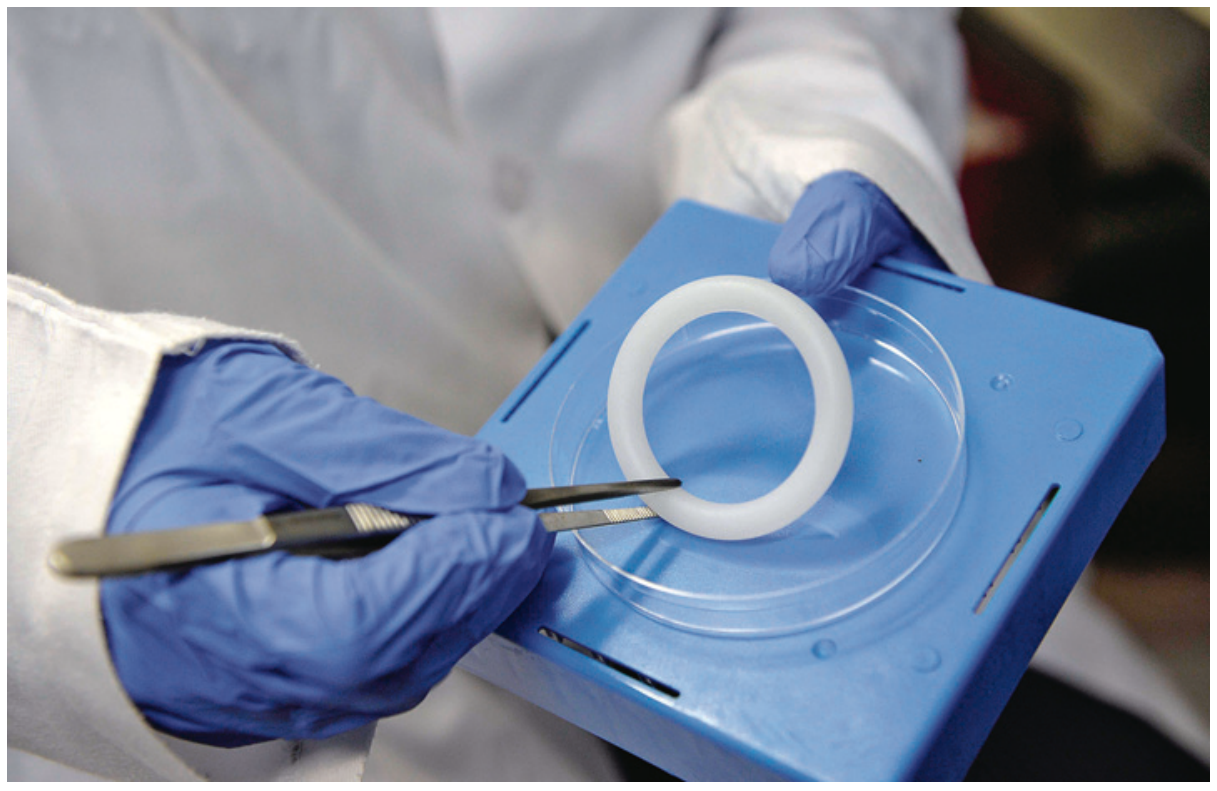

Dapivirin vaginalring. Foto: AFP/Stephane de Sakutin/NTB scanpix

Mer enn 35 millioner mennesker er smittet av hiv-1-viruset, og de fleste av disse bor $\mathrm{i}$ Afrika sør for Sahara, der smitterisikoen for unge kvinner er høy. Forebyggende behandling med antivirale legemidler er en lovende tilnærming for å beskytte mot smitte, men kliniske studier har tidligere vist lav grad av etterlevelse ved bruk av tabletter og vaginalkrem med antivirale legemidler.

I to nye studier har man vurdert effekten av vaginalringer med det antivirale legemidlet dapivirin hos seksuelt aktive kvinner i alderen 18-45 år fra Sør-Afrika, Uganda, Malawi og Zimbabwe $(1,2)$. De to studiene inkluderte totalt 4588 kvinner som ble randomisert til bruk av vaginalring med eller uten dapivirin. Kvinnene byttet selv vaginalring hver måned. I tillegg til vaginalringene fikk de utdelt kondomer, og de ble hivtestet regelmessig.

I begge studiene hadde dapivirin en forebyggende effekt, med en reduksjon av hivsmitte på henholdsvis $31 \%$ og $27 \%$. Den beskyttende effekten var dårligere hos de yngste kvinnene, men dette funnet var statistisk signifikant kun i den ene studien, der man fant at kvinner på 25 år eller over hadde $61 \%$ reduksjon i risiko, mens det ikke var signifikant effekt hos dem under 25 år. Dette korrelerte med dårligere etterlevelse av bruken av vaginalring hos de yngste kvinnene.

Forfatterne av begge studiene konkluderer med at riktig bruk av vaginalring med dapivirin gir moderat reduksjon av hivsmitte hos kvinner i Afrika sør for Sahara.

\section{Kristoffer Brodwall}

Barne- og ungdomsklinikken

Haukeland universitetssykehus

Litteratur

1. Nel A, van Niekerk N, Kapiga S et al. Safety and Efficacy of a Dapivirine Vaginal Ring for HIV Prevention in Women. N Engl J Med 2016; 375 2133-43.

2. Baeten JM, Palanee-Phillips T, Brown ER et al. Use of a Vaginal Ring Containing Dapivirine for HIV-1 Prevention in Women. N Engl J Med 2016; 375: $2121-32$. 